\title{
The Relative Pay Of Public Employees In The U.S.: \\ An Assessment Of Empirical Research
}

Josefa Ramoni, (E-mail: jramoni@ula.ve) Universidad de los Andes, Venezuela

Don Bellante, (E-Mail: dbellant@coba.usf.edu) University of South Florida

\begin{abstract}
Beginning in the 1970's and continuing to the present, economists have examined the pay of public sector employees. Usually, an attempt is made to compare the compensation of public employees at various levels of government to workers in the private sector who are believed to be comparable. Of the many studies done, there is substantial variation in the operational meaning of "comparable." Nonetheless, the general finding is that public employees on average receive rents or, stated otherwise, are overcompensated when compared to employees in private employment. The estimated levels of rent seem to be highest at the federal and lowest at the local level of government. Despite the general finding, there are substantial differences in the quantitative estimates. The major focus of this paper is on a critical evaluation of the various empirical methodologies that have been employed. An attempt will be made to reconcile the differences observed and to suggest improvements in the method of estimation.
\end{abstract}

\section{Introduction}

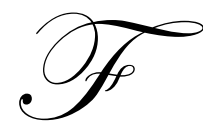

or many years, the idea that earnings paid to public sector workers were far above those received by their private counterparts generated a debate about the size of government, the efficiency of the public wage-setting system, its contribution to fiscal stress and the proper use of tax funds. In general these studies were conducted by private academic researchers based on comparisons of individuals' characteristics under the argument that workers with similar productivity-related characteristics should be paid the same regardless the sector of employment.

Total compensation received by public servants during the last three decades appears to have risen faster than that for private sector workers. These wage raises have been justified by government-conducted studies that tend to suggest that public sector employees are underpaid compared to private sector workers with similar occupations, especially high-skill workers. Efficiency and equity principles indicate that government should pay no more than what is necessary to attract a sufficient supply of workers, and that a worker should be equally attracted to either the public or the private sector. But even though common sense indicates that both sectors should pay the same for similar jobs, several reasons can explain compensation differences between both sectors:

First, the wage-setting system in the public sector is not the same as the one applied in private industry. The profit considerations of the private sector that yield competitive wages is replaced in the public sector by a comparability process ${ }^{1}$ that has proven to be unable to produce the market-clearing wage that would result in a profit maximizing environment. Federal wages, for example have been shown to be less sensitive to changes in local labor markets and changes in workers skills, compared with the private sector, so that distortions in the public pay are

\footnotetext{
${ }^{1}$ Since 1862 when the comparability principle first passed for federal blue-collar workers, making their wages comparable to those in the surrounding private sector, many adjustments have been made to it. The resulting pay system is set on an area basis for blue-collar workers and on a national basis for white-collar workers. For a more complete explanation of the evolution and failure of the comparability system see Smith (1974a, 1982).
} 
increasing (Smith, 1982). This pay-setting system is based on surveys conducted by the Bureau of Labor Statistics (BLS) on nonfederal salaries for a selected sample of jobs that are similar to federal jobs. However only a few jobs in the public sector are really comparable to jobs in the private sector. Moreover, to minimize costs this survey only examines wages paid by firms of a specific minimum size, which introduces an additional bias resulting from the positive relationship between firm size and wages. Therefore, even if it intends to equalize wages between sectors, the government is unable to do so because of the lack of knowledge or capability (Van Ophem, 1993).

Second, public sector workers have inordinate political influence. Political issues can also distort public sector wages, since public servants are more likely to affect government pay decisions through their votes. In general voters become informed about the issues they care for (rational ignorance), and public workers are those with the strongest interest in the pay-setting issue. Therefore, public wages are influenced by the size of budget and voters' wishes: government wages depend on public workers' ability to compete with other groups over the allocation of the public budget, and with taxpayers over the size of this budget (Gunderson, 1979).

Third, there may exist spurious compensation differences due to technical problems. Empirical researchers have used data and/or techniques that can be inadequate to test the null hypothesis of no compensation differences. For instance comparisons usually are based only on wages, ignoring differences in fringe benefits that represent an important portion of total compensation, as well as nonpecuniary attributes of the jobs (stability of employment, social status, complexity, working conditions, etc). These other ways of "remuneration" are generally perceived as favoring public sector workers, and could justify lower monetary wages in that sector, according to the principle of compensating differentials. Some investigators have neglected the selectivity bias that arises from the fact that workers are not randomly allocated to each sector, to unions, and that even the labor force participation decision is not random. Other sources of bias come from measurement errors, ${ }^{2}$ interdependence of wage settlements across geographic areas and/or occupations, cyclical factors, or from the omission of unobserved differences in productivity of the worker, such as ability and motivation. Besides, as previously mentioned, human capital models tend to suggest public wage premiums, while models based on job attributes oppose that idea, so that the approach used matters.

Given the difficulties in answering the question about whether comparable workers performing comparable jobs are compensated the same in the public sector and in the private sector, the majority of the studies have been limited to either comparing earnings within narrowly defined job classifications and for specific jobs, or analyzing earnings of workers with similar measurable characteristics, controlling when possible for job attributes. In general they are based on human capital models amplified by some other measurable job-related variables of the form:

$\mathrm{Y}=\beta^{\prime} \mathrm{X}+\delta^{\prime} \mathrm{Z}+\varepsilon$

where $\mathrm{Y}$ is the natural logarithm of wages or earnings, $\mathrm{X}$ is a vector of productivity-related characteristics of workers, $\mathrm{Z}$ is a vector of job-related or other socioeconomic variables, and $\varepsilon$ is a random error. The equation, generally estimated by Ordinary Least Squares (OLS) or Maximum Likelihood (ML) methods, applied to each sector yields results that can be decomposed to estimate average wage differentials using a Oaxaca-type decomposition as follows

$$
\overline{\mathrm{Y}}_{\mathrm{g}}-\overline{\mathrm{Y}}_{\mathrm{p}}=\left[\left(\overline{\mathrm{M}}_{\mathrm{g}}-\overline{\mathrm{M}}_{\mathrm{p}}\right) \hat{\beta} *\right]+\left[\overline{\mathrm{M}}_{\mathrm{g}}\left(\hat{\beta}_{\mathrm{g}}-\beta^{*}\right)-\overline{\mathrm{M}}_{\mathrm{p}}\left(\hat{\beta}_{\mathrm{p}}-\beta^{*}\right)\right]
$$

with $\overline{\mathrm{M}}_{\mathrm{s}}$ a matrix of average individuals and job characteristics in sector s, where s equals is either public (g) or private (p), $\hat{\beta}_{\mathrm{s}}$ the corresponding estimated returns of these characteristics, and $\beta^{*}$ their return under equality. The first component indicates wage differences due to differences in average worker characteristics and job attributes;

\footnotetext{
${ }^{2}$ The CPS survey, the most common source of data used to analyze wages, has proven to have measurement errors such as errors in employment and union status, and under-reporting of income especially for men in the lower end of the income distribution (Bollinger, 1998).
} 
the second term reduces to $\left[\overline{\mathrm{M}}_{\mathrm{p}}\left(\hat{\beta}_{\mathrm{g}}-\hat{\beta}_{\mathrm{p}}\right)\right]$ when $\beta^{*}$ is set equal to $\hat{\beta}_{\mathrm{g}}$, and represents the differences in compensation due to differences in the returns to these characteristics and attributes, called rent. However, if a dummy variable representing sector of employment were introduced in the right- hand side of a wage equation, its parameter would provide information on the public/private compensation differential. In general, this equation is applied on micro-data for nonagricultural workers, sixteen years of age and older.

\section{Early Empirical Studies}

The first attempts to estimate wage differentials between public and private sectors can be traced back to the 1970s with a series of studies conducted by Sharon Smith. In her analyses on this issue, she stresses the importance of the differences in wage structure among sectors, resulting from differences in the wage-setting systems, and the possibility of discontinuous working periods. To account for the first point, she experiments with two different approaches, estimating separate wage equations for each sector along with single equations considering sector of employment as a dummy variable. Experience is usually estimated as age minus years of schooling minus six. In a common 'Mincerian' human capital function, marginal returns to schooling and experience are assumed to decline monotonically. But as Mincer recognizes, this assumption is not always valid for the experience variable (Mincer, 1970). Particularly, he specifies the case for women, whose cyclical participation in the labor force is subject to "family" circumstances. These interruptions reduce also their on-the-job training, and constitute the main reason why many studies exclude women from their samples. To overcome the problem and still include women in the analysis, Smith proposes to control for the two most important variables that affect women participation in the labor force: marital status and family size in all her studies. She uses a three-way classification of marital status by itself and interacted with experience: single-never-married; married-spouse-present; marriedspouse-absent.

Smith $(1977,1981)$ applies OLS to estimate separate human capital models by sex for the public sector at three different levels, and for the private sector, correcting also for some socioeconomic variables such as race, veteran status, size of urban area, two-digit occupation, part-time and union status, dual-job situation and region. The public/private wage differential is then decomposed to recognize the reasons for the existence of such differences. With data drawn from the 1973 and 1978 May Current Population Survey (CPS), she concludes that, in general, the public sector pays more than the private sector, but the size of the premium varies with sex and level of government. Wages are higher in the federal sector than in the private sector, particularly for women and nonwhites, perhaps due to antidiscrimination policies that are more effectively applied in the public sector. This gap decreases with the level of government. At the local and state levels, male workers receive similar or even lower wages relative to male private workers, while women are paid comparable wages relative to private sector workers. A significant part of this gap appears to be explained by workers' influence in the wage-setting process. In fact, at most 36 percent of the wage premium appears to be explained by workers characteristics related to productivity. These findings are supported by those in earlier papers (Smith, 1974a and 1974b), where the author evaluates the effect of the comparability policy by analyzing earning differentials between public and private sectors, considering either just federal workers or all of the three levels of government. She also finds that race and sex differentials are larger in the private sector. A series of studies surveyed by Ehrenberg and Schwarz (1986), some of which are summarized in Table 3.1, indicate that there exists a public wage premium, especially for women, that decreases with level of employment and that appears to have diminished during the 1970s. ${ }^{3}$ Later on, in 1989 Belman and Heywood reproduce Smith's work but disaggregating the public sector between public administration and nonpublic administration. With data from the May 1978 CPS they find that the average public administrator receives a premium of approximately 4.9 percent compared to private sector workers, and of 10 percent relative to nonpublic administration workers, but the average public sector employee is overpaid by just 1 percent. This is because the public administration workers tend to be lawyers, accountants, and other professionals in the highest paying levels.

\footnotetext{
${ }^{3}$ It is clear that these studies cannot be truly comparable since they are based on different samples, and differ in the measure of earnings used and in the explanatory variables included.
} 
In 1991, Moore and Raisian try to test the hypothesis of a declining wage premium in the public sector, by updating ${ }^{4}$ the work done by Smith, but controlling for some job characteristics such as size of the firm and long-term average unemployment rate in an industry. ${ }^{5}$ The coefficient for the first variable is expected to be positive, since large firms in theory pay higher wages to attract a greater and better labor force, or firm size can be considered as a proxy for undesirable working conditions. Industry unemployment is considered as a way to test for compensating wage differentials, assuming that higher unemployment risk should lead to higher wages. Sector of employment enters the equation either as a dummy or by separately estimated equations.

They observe that during the 1970s, public sector workers were paid comparable wages to those in the private sector. However, during the early 1980s, public sector workers experienced a negative wage premium. Within the public sector, an exception was for federal workers who earned a significant but declining wage premium over the entire period. This result is consistent with the argument that wages at state and local levels are more subject to the scrutiny of taxpayers. The authors conclude that the government wage premium decreases with the introduction of firm size at the federal level and increases at the local level. Perhaps this is due to the fact that the federal government tends to include larger "firms". ${ }^{6}$ The very concept of "firm size", however is highly problematic when the subject is governmental units. It may well be the case that the attempt to control for firm size merely disguises true public-private wage comparisons. They also provide fixed effects ${ }^{7}$ estimations based on workers shifting from one sector to another, to control for the effect of unobservable skill differences between public and private sector workers. However, the small difference between the wage premiums obtained with both methods indicates that just a few individuals' qualities appear not to be included in the original model. Studies considering the effect on wages of other job attributes such as repetitive activities, stress, physical strength, bad working conditions (Brown, 1980; Hundley, 1993), supervision of others, hours flexibility, sedentariness (Lucas, 1977), fatal and nonfatal risk (Herzog and Schlottman, 1990), ${ }^{8}$ among others, are very common in the literature on compensating wage differentials. Unfortunately these studies do not consider the case of public/private compensation differentials, at least for the United States, except for Brown (1980) and Hundley (1993). In particular, Hundley includes a variable representing the time required to learn the technique and acquire the information and skills necessary to perform the job. Its negative coefficient indicates public pay compression. They both find evidence of a public wage premium, but not necessarily due to the job attributes considered.

The importance of the size of employer and/or establishment as a factor generating a compensating differential was also analyzed by Linneman and Wachter (1990) and Belman and Heywood (1993b). The first article argues that since the idea is to compare wages between identical workers employed in different sectors, workers' characteristics and some other variables reflecting compensating differentials (region and city size) should be held constant, allowing only for variations in job-description variables: union status, employer size and establishment size. The second article introduces the size of the firm in the wage equation after estimating the private sector employer size distribution function through an ordered probit and then using this equation together with federal employees' characteristics (neither study considers state and local levels), to obtain a private-sector firm size for each federal worker. Their estimates for year 1983 (CPS) indicate that the larger the size of firm, the higher the wage differential, but with this wage premium varying within a wide range (16.90 percent and 5.75 percent, respectively).

\footnotetext{
${ }^{4}$ They use data from the Panel Study of Income Dynamics (PSID, 1970-1979) and the CPS (1979-1983). They just consider for the public sector individuals working in public administration, legislature, uniformed services, and administrative departments. Teachers, workers in public medical facilities and nonpublic administration workers were included in the private sector.

${ }^{5}$ The effect of some job characteristics such as compensating wage differentials was already analyzed by Brown (1980). He included variables for repetitive activities, stress, physical strength, and bad working conditions. He found evidence of a public wage premium, but not due to the job attributes considered.

${ }^{6}$ The general literature indicates that wages and plant size are positively correlated in private industry.

${ }^{7}$ According to Moffit (1999), the techniques with the largest increase in usage in the labor economics field over the 1986-1996 period are instrumental variables and fixed effects models. However, fixed effects are rarely used to compare wages across sectors in United States. This methodology is very common in studies testing for compensating wage differentials in general. ${ }^{8}$ For a complete survey of the literature on the effects of risk on wages, see Fishback (1998).
} 
The idea of a narrowing wage gap between public and private sectors does not necessarily mean that the comparability policy has been able to reduce the wage differential public workers enjoy, especially those working at the federal level. As stated previously, this can result from a series of technical and conceptual considerations, in particular differences in the labor force composition between sectors.

Belman and Heywood (1993a) present estimates of a human capital model after controlling for some demographic and occupational factors, in order to compare wages among federal, state, local and private sector workers. The results obtained from the 1989 CPS Annual Earning Profile indicate no evidence of wage premium for public workers, contradicting the common finding of overpayment at any government level. They attribute this result primarily to the fact that, in general, studies neglect occupational comparability: "one must compare like with like: accountants with accountants and not with sales clerks, college graduates with college graduates and not with high-school dropouts." A series of papers comparing wages for specific occupations, especially those that have similar counterparts in private sector such as lawyers, teachers, postal service workers, nurses and physicians, tend to indicate that public workers in these categories are underpaid. An explanation frequently given to this differential is that of the donative-labor hypothesis, under which workers derive some utility from the nature of the service they offer (intrinsic value of job) or because they want to guarantee that their efforts are helping to achieve idealist goals. ${ }^{10}$

A more recent study using data from the March 1991 CPS to estimate a similar human capital model, but ignoring occupational categories, contradicts these results (Choudhury, 1994). ${ }^{11} \mathrm{He}$ also finds evidence indicating that wages increase with education and experience in both sectors, more for men than for women. Buckely (1996), and Gregory and Borland (1999), using data from the Bureau of Labor Statistics' Occupational Compensation Survey (OCS), show that this wage premium does not disappear when controlling for occupational comparability. They compare compensation between public and private sectors by examining wages paid to workers within narrowly defined occupations, correcting both for differences in productivity-related characteristics of workers and for job attributes. They find evidence supporting the hypothesis that there are positive wage premiums for public sector employees, especially for white-collar workers. However, using the same source of data, Miller (1996) finds that white-collar workers are better paid in the private sector, and their pay rises faster with the level of duties and responsibility, relative to public workers. Lower-paying jobs, on the other hand, are paid better in the state and local sectors than those in the private sector. Based on the simple comparison of the Employment Cost Index (ECI), Schwenk (1999) analyses differences in wages between private and state and local governments over the period 1981-1999. He observes that wages in the three sectors follow similar patterns, increasing by about the same rate during the 1980s, but with a faster increase in the private sector at the end of the period. On average, wages were increased by approximately 216 percent in the state and local governments and 205 percent in the private sector. These differences can be explained by differences in the occupational structure of their work forces. In fact, whitecollar occupations are more common in the public sector (71.2 percent compared to 55.1 percent in the private sector), while blue-collar jobs are more common in the private sector ( 29.8 percent compared to 8.2 percent in state and local levels). Also, workers seem to be spread among a wide variety of job categories in the private sector, but concentrated in the service industry (62.8 percent) and public administration (31.8 percent) in the state and local sectors. According to Schwenk, because of these differences in industry and occupation mix, any study comparing wages between both sectors should control for them.

Musell and Masia (1998) compare public/private wage differentials in light of both the worker-based approach and the job-based model. They analyze the possible reasons for inconsistent results in the general literature on the topic, contrasting the ordinary least squares estimates of human capital and expanded models, based on data from the National Longitudinal Survey for Youth (NLSY). Their results for a pure human capital model suggest that federal workers are overpaid, but the premium decreases once firm size, region and occupational group are controlled for, and becomes almost negligible if aptitude, tenure, local unemployment rate and union status are included in the right hand side of the equation. Therefore, according to Musell and Masia, federal servants are

\footnotetext{
${ }^{9}$ Ibid. (p.1)

${ }^{10}$ Evidence from profit/nonprofit wage comparisons does not support the donative-labor hypothesis (Leete, 2001).

${ }^{11}$ In fact, it is not possible to compare similar jobs in both sectors using CPS data since occupations in each sector are different. In this study, the author does not disaggregate public sector by levels.
} 
neither underpaid nor overpaid based on their human capital endowments. By this reasoning it is not that the public sector is paying wages above private sector wages; it is just buying less human capital for similar jobs.

Changes in the labor force and wage structure in the United States have been well documented by several studies (Krueger and Summers, 1988; Bound and Johnson, 1992; Katz and Author, 1999; Acemoglu, 2002). In general these studies point out technological change and its resulting increasing demand for skilled workers as the main source of changes in the composition of the labor force (technological bias). Besides the differences in the labor force structure in public and private sectors, it is possible that differences in average earnings are due to differences in the wage distribution between sectors.

Only a few studies have undertaken the comparison of wages by their position in the distribution in the United States, but the general conclusion is that the public sector compresses the distribution of earnings of its employees relative to those in the private sector. In other words, the dispersion of earnings is higher in the private sector. Katz and Krueger (1991) analyze differences in labor force structure between public and private sectors and their effects on wages. According to the authors, the wage structure during the 1970s and 1980s in the United States can be described by its acute changes and increasing wage dispersion in general terms: the college wage premium as well as the experience premium expanded. But these changes appear to have been stronger in the private sector, and then transmitted into the public sector. In their paper, data from different sources ${ }^{12}$ are used to estimate appropriate wage equations in order to analyze how these changes affect wages in the private sector and in the different levels of the public sector, emphasizing the effects of changes in skill differentials and local labor market conditions on public sector wage policies. Two important results are worth noting: First, their analysis corroborates the presence of higher wages in the federal government relative to wages paid to private sector workers, while state and local sector workers earn less. The federal wage premium appears to be especially large for women. Despite these results, skill differentials in the public sector show stable behavior, as opposed to the large expansion experienced in private sector. In particular, high-skill workers in the federal government earn less than high-skill workers in the private sector. However, less-skilled workers at the state and local governments earn more, relative to comparable private sector workers. Second, the federal government appears to be insensitive to changes in local labor market conditions, perhaps due to a single national wage schedule for most of its workers. The private sector, as well as state and local governments, adjust their overall wage levels in response to economic, and therefore budget conditions.

Based on data from the US Decennial census and the CPS for the period 1960-2000, Borjas (2002) documents the differences in wage structure between the public and private sector, and their impact on the sorting of workers across sectors. He concludes that due to the relative wage compression in the public sector observed since the 1970s, it is more difficult for the government to attract and retain high-skill workers. These results illustrate the problems faced by the government in recruiting and retaining employees of different skill levels, especially college graduates, since their skills are highly valued in the private sector. This can explain the recent expansion of job queues for blue-collar jobs and contraction of job queues for white-collar jobs at different levels of public administration. Some explanations for this wage rigidity suggested by Katz and Krueger prove to be incomplete: bureaucratized personnel systems tend to be inflexible; wages in not-for-profit organizations are usually insensitive to changes in the market and skill conditions; declining unionization in the private sector is raising skill differentials and wage inequality, since unions usually narrow skill differentials.

Katz and Krueger (1991) do not correct for differences in the distribution of worker characteristics between sectors. Poterba and Rueben (1994) hypothesize that there are three sources of differences in public and private sector wage distributions: Differences in the distribution of worker characteristics, differences in the returns to these characteristics, and differences in the distributions of unexplained wage residuals across sectors. This is the first and only study to apply quantile regression to the analysis of the distribution of the public sector wage premium. With data drawn from the CPS over the period 1979-1992, and considering state and local government workers combined into one single pool, along with private sector workers (not self-employed), they estimate the qth quantile of the conditional wage distribution as a linear function similar to Smith's:

\footnotetext{
${ }^{12}$ National Income and Product Accounts, CPS, Full Year Outgoing Rotation Group files, Central Personnel Data File.
} 
Quant $_{\mathrm{q}}\left(\operatorname{Ln~W}_{\mathrm{k}} \mid \mathrm{X}_{\mathrm{k}}\right)=\mathrm{X}_{\mathrm{k}} \beta_{\mathrm{qt}}+\mathrm{GOV}_{\mathrm{kt}} \delta_{\mathrm{qt}}$

where $X_{k}$ is a set of individual characteristics that includes education, experience, marital status, race, metropolitan statistical area (SMSA), and part-time work for individual $k$, and GOV is a dummy variable that equals one if the individual works in private sector at period $t$. They also consider the possible link between workers' attributes and the public sector wage premium by incorporating the interaction between sector of employment and level of education as an explanatory variable. Their findings suggest that the level of the wage premium changes with the choice of the quantile, but not its pattern over time. The public sector wage premium is higher at the lower end of the wage distribution and decreases monotonically as one moves to the upper end.

A common result in the literature is that women are better paid in the public sector than in the private sector [Smith (1974b, 1977); Katz and Krueger (1991); Moore and Raisian(1991); Belman and Heywood (1993a, 1993b, 1995)], perhaps due to a stricter application of antidiscriminantion policies by the government. However, it is well known that women earn less than men despite these policies. The remedy could be the application of wage-setting systems that eliminates the portions of wage differentials due to gender discrimination, which implies the use of common standards to set wages in some specific jobs. Comparable worth programs try to translate job attribute measures into the appropriate wage and are occasionally used as the base to measure male/female wage discrimination within a specific sector. Hundley (1993) compares public/private relative pay before, during and after comparable worth programs. Using data from the May 1985 CPS and using the traditional socio-economic variables in a human capital wage equation expanded to include occupational categories and job attributes, he finds that when these programs are implemented through wage increases in state and local governments, public sector wages moved far from the comparability principle, because their wages were already above those paid in private sector.

Studies of public/private compensation comparisons are in general based on nationwide data, or at most on pooled data for regions or specific states as in Smith (1974a). Differences among regions are usually introduced in the wage equations as dummy variables that control for the effect of differences in cost of living, unemployment rates, and local labor markets. However, their results may be inaccurate due to aggregation bias leading to the conclusion that wages are comparable when in fact there are intrastate or intraregion offsetting differentials. To avoid these problems, Belman, et al. (1994) compare private, state, and local wages for Wisconsin, while Belman and Heywood (1995) compare wage differentials for seven states: Wisconsin, Illinois, Indiana, Ohio, Michigan, California, and Mississippi. The methodology applied is always the same: estimate separate earnings equations for each sector controlling for some individuals characteristics including education, experience, race, sex, marital status, urban area, category of employment, and union and part-time status. They find that state workers earn more than their private counterparts in Wisconsin and California. Local sector workers are underpaid in all states except California. Therefore, state and local comparisons based on national aggregations are misleading. According to the authors, these intrastate differences can be explained by differences in productivity-enhancing characteristics of workers across states. They also conclude that, in general, wages in the public sector are more compressed around the mean compared to private wages; in other words, public sector earnings are relatively higher at the lower end of the pay hierarchy and relatively low at the top. Kroncke and Long (1998) compare earning differentials between state and private sector workers for each state using 1990 Census data. They observe that earning differentials are not uniform across states, but in general the average state government pay is higher because it hires relatively more highly educated workers. However, returns to human capital investment appear to be lower in the public sector, especially for men. More recently, Kaatz and Morris (2000) compare private, state, and municipal wages in Mississippi. With data for years 1995 and 1996 and only comparing average wages for very disaggregated levels of occupations, they conclude that public sector workers earn less than private sector workers performing the same job, especially in small cities where the public sector does not need to compete with large private industries.

\section{Methodology Changes}

The models described above can be considered as slight modifications of the methodology used by Smith. Even though their results are not always consistent and yield a wide variety of measures of wage differentials between public and private sectors, they seem to indicate that workers in the public sector tend to be paid a wage premium, the magnitude of which decreases with the level of government and with the level of education. Most of 
the studies were published prior to the development of methodological techniques for handling some of the sources of bias described at the beginning of this chapter. Of particular importance is the sample selectivity bias that arises when researchers ignore that the labor force participation decision, the sectoral choice decision, union participation, educational attendance and other variables usually considered in the right hand side of the wage equation that are not random. In fact, if wage structures differ across sectors and/or groups, workers will select the option providing them the greater net benefit, according to their own observed and unobserved characteristics. For example, one factor that determines individuals' self-allocation into the public or private sector is the degree of preference for non-risky jobs. In general, studies assume that individuals are risk neutral or that workers' risk aversion is the same in both sectors. Generally unemployment rates in public and private sectors are used as proxies for the risk faced by workers of losing the job. However as Bellante and Link (1981) show, after controlling for some demographic characteristics, risk adverse individuals tend to prefer public sector employment. Therefore these assumptions of risk neutrality or risk equality are not correct. Several studies have attempted to test the hypothesis of general increasing job instability without reaching any consensus [Diebold, et al., (1997); Gottschalk and Moffit, (1999); Jaeger and Stevens, (1999)]. According to Bernhardt, et al. (1999), public sector employment seems to enjoy a higher but also declining job security compared to the private sector. This trend does not disappear once the worker settles down, and is not limited to less-educated workers. The term of selectivity bias was first used by Gronau (1974) when he pointed out that the wage rate a person receives depends on both the wage offered and the job-search strategy he follows. The higher his expectations, the higher the wage he will receive, and the lower the probability of finding such a job. Differences in search strategies that affect the probability of finding a job should be considered when comparing wages among sectors to avoid the bias resulting from considering only the observed wages. But the empirical selection bias model really began with the work of Heckman (1974) on wages and labor supply. Although sample selection bias is very common in the literature on union/nonunion wage differentials and its effects on productivity (Duncan and Leigh, 1985), it has not been extensively applied to public/private wage comparisons, at least not in the United States. One possible reason seems to be a lag in the incorporation of 'new methods' in labor economics analysis, probably due to unavailability of computational software for such methods. Another reason is perhaps that wage differentials was one of the most rapidly growing bodies of research on public sector labor markets during the 1970s and 1980s, when the sample selection bias was known, but the methodological techniques for handling it were lacking. The main interest of labor market researchers may have then switched to other issues such as interindustry wage differentials due to technological bias, and its relation with globalization processes, unionization trends and immigration. The concern about public wage premiums may have appeared later in time in other countries, whose researchers learned from the United States' experience and were aware of the approaches already available to obtain more accurate results.

Gyourko and Tracy (1988) represents the first attempt to estimate wage differentials between public and private sectors in the U.S., with both union and government status treated as endogenous, ${ }^{13}$ instead of simply using dummy variables as in previous studies. They follow the Lee two-stage procedure, a modification of Heckman's method, where a multinomial logit selecting model is estimated considering four possible choices: private/nonunion, private/union, public/nonunion, public/union as a function of the traditional demographic variables (marital status, race, sex, veteran status, education, and region). The results are then used to estimate conditional and unconditional human capital wage functions for federal, state, local and private sectors, ${ }^{14}$ with the cost-of-living index included as a separate regressor. Their results, based on data from the May 1977 CPS, indicate a significant positive wage premium for government workers at any level, but a particularly large one for federal employees. Also, the wage gap generated by unions is smaller in the public sector than in the private sector. Based on the selection forces that affect job switchers as a way to overcome selectivity problems, Krueger (1987) used longitudinal data to examine the change in a worker's wage as he moves from one sector to another, controlling for the individual characteristics that remain fixed as he changes jobs. His findings reveal that the average federal worker receives a higher wage compared to private sector counterparts.

\footnotetext{
${ }^{13}$ Blank (1985) modeled how people allocate themselves between the public and private sectors, but did not use the results to estimate any wage equations.

${ }^{14}$ The conditional model includes the selection effects when calculating the expected wage in each sector.
} 
In the most recent papers on sample selectivity bias applied to the issue of comparing public and private sector wages, Choudhury (1994) and Hoffnar and Greene (1996) use a model for double-sample selectivity bias. It entails estimating two probit models, one for predicting the labor force participation decision, considering the whole sample (labor force participants and nonparticipants), and the other modeling the sectorial choice based on the susbsample of employed workers who work in either the public or the private sector. The specification of the wage equations uses the conventional demographic and human capital variables, but includes the two estimated inverse Mill's ratios. With data from the 1991 CPS, Choudhury finds that men working in the public sector on average earn more than men in the private sector, whereas the wage premium earned by women in the public sector is weakened by the effect of discrimination. Hoffnar and Greene, more concerned about estimating gender earnings gaps by race in public and private sectors, consider separate wage equations for whites and African-Americans. With data from the March 1990 CPS, they conclude that both white and African-American male workers are paid substantially more than white and African-American female workers in both sectors, but this gender gap is smaller in the public sector, being almost zero for the second group.

\section{Studies Incorporating Non-Wage Compensation}

Another problem in making wage comparisons between the public and private sectors is that they ignore other aspects of total compensation, which include both nonwage pecuniary benefits (fringe benefits ${ }^{15}$ ) and nonpecuniary (working conditions) forms of pay. In a competitive labor market, equality in total compensation and not just in wages is expected. Comparing fringe benefits across sectors is more difficult than comparing wages due to differences in options, and lack of information. The proliferation of different fringe benefit combinations make the valuation of plans difficult, and an accurate comparison impossible. Each plan treats individuals differently depending on the sector of employment, age, tenure, etc. Moreover, not all benefits can be translated into dollars, as is the case of job security, working conditions, probability of promotion, and access to on-the-job training programs.

According to Foster (1997), the average total cost for employee compensation is larger in the public sector than in the private sector ( $\$ 25.73$ versus $\$ 17.49$ per hour), but the proportion of these costs due to benefits is very similar (about 30 percent). The incidence of these employer-provided benefits however is different and difficult to compare. During the 1990s, for example, benefits such as medical and dental care, paid sick leave, and life insurance were more common among public sector employees. The differences in costs and provision of benefits partly reflect differences in occupations, and make it difficult to compare them between sectors.

A more detailed analysis can be done by selecting specific benefits, retirement benefits being among the most important. In fact, pensions represent 7.4 percent of the total benefits in the public sector and 3.1 percent in the private sector. In her study, Foster (1997) compares pension plans between private, public, and state sectors. Using data from the EBS, she observes there are substantial differences in these plans. In the public nonfederal sector for example, 72 percent of the workers contribute to the costs of their own pension plans, contributing about 6 percent of their earnings, while 97 percent of private sector workers enjoy benefits paid entirely by employers. However, the former group receives benefits that are larger compared to those in the private sector, are more likely to participate in cost-of-living adjustments, and can retire earlier with unreduced pensions (minimum retirement age tends to be 55 in the public sector and 65 in the private sector).

Many authors have recognized that the failure to account for differences in fringe benefits, and other nonpecuniary benefits tends to bias the wage differential conclusions [Brown (1980); Bellante and Long (1981); Krueger (1987); Moulton (1990)]. Nonetheless only a few studies have attempted to examine wage differentials adjusted for the provision of such benefits. One approach compares quit rates in both the public and private sectors, assuming that lower quit rates in the former can be taken as evidence that government employees receive higher total compensation, since workers consider differences not only in wages, but also in benefits and working conditions. Ehrenberg and Schwarz (1986) suggest that better monetary and non-monetary conditions of

\footnotetext{
${ }^{15}$ The Employment Benefits Survey (EBS) provides a list of all the benefits workers receive, such as paid leave, disability, medical and dental care, life insurance, funeral services, and retirement benefits. For a complete list of benefits and the participation of workers in their costs see Foster (2000).
} 
employment should lead to lower quit rates, which are lower in the public than in the private sector. Even though studies in general show lower quit rates in the public sector, the interpretation of these results may not always be valid. Gregory and Borland (1999) point out some reasons for this possible misinterpretation. First, optimal rates of turnover may differ between the private sector and the public sector. There exists evidence that worker turnover rates decrease with the size of establishment, and average establishment size is larger in the public sector than in the private one. Second, these studies do not control for job characteristics and amount of specific training, which is known to have a negative relationship with the probability of leaving a job. Finally, differences in the level and timing of pensions can account for these differences. Long (1982) shows that public workers are less likely to quit. Ippolito (1987) argues that the low quit rate in the federal sector is due to substantial pension losses imposed on workers who quit early. This is because federal pension benefits are based on nominal wages at the time of leaving, and because pension benefits make up a larger share of total compensation in the public sector than in the private sector. Belman and Heywood (1993a) suggest that any comparison of quit rates should be done controlling for individual characteristics, including occupational and educational attainment. They find no significant support for differences in tenure between comparable workers in the public and private sectors. Cox (1996) on the other hand, sees the relative higher federal employee tenure as an indicator that federal employee compensation is above the market rate. Another approach analyzes queues: if individuals perceive government employment relatively more attractive, one could expect longer queues of applicants for government openings than for private sector jobs. In these models, a worker's utility is a function of observable employment characteristics and public/private wage differentials. An applicant will choose to work in the sector providing the highest level of utility. Studies of this sort generally support the hypothesis of a higher number of applicants for the majority of the jobs offered in the public sector. Krueger (1987) uses job queues data to compare the number of individuals who apply for jobs in the federal government with the number who apply for jobs in the private sector. He finds that for the average job opening, the federal government receives more outside applicants than does the private sector.

Some studies have examined specific components of fringe benefits or particular job attributes. Quinn (1982) compares pension plans between different levels of government and the private sector. Using data from the 1969 Retirement History Study that includes information on pension plans and Social Security records, he runs regressions of wealth levels on years of job tenure, final wage rate and sector dummy variables, in both linear and logarithmic form. Wealth levels are adjusted for employers' contributions, Social Security coverage and inflation protection. ${ }^{16} \mathrm{He}$ concludes that pensions are more attractive in the public sector than in the private sector, especially for federal and state employees. Similar results about pensions are obtained by Lovejoy (1988) and Mitchell and Smith (1994). Heywood (1991) compares the public and private provision of what he considers to be the five major fringe benefits (retirement programs, health insurance, life insurance, vacation leave and sick leave). Using data from the 1977 Quality of Employment Survey, he regresses a probit model for each of these fringe benefits using experience, education, race, sex, SMSA, tenure, trade school attendance, regional dummy, plant size, and union status as explanatory variables. Additionally, he uses a dummy variable to identify government workers grouped together or disaggregated into federal, state, and local sectors. The government employment variable is highly significant, increasing the probability of receiving all the benefits, except health insurance, which says that government employees enjoy substantially larger compensations than private workers. Within the government sector, the provision of fringe benefits is particularly strong at the local level. A broader comparison is undertaken by Braden and Hyland (1993). They observe that public sector workers' average hourly total compensation is about $\$ 23.50$, almost 50 percent higher than private industry workers $(\$ 16.14)$. Two thirds of this gap is due to wage differences, and one third corresponds to differences in benefits. ${ }^{17}$ The difference in total compensation is particularly large for service workers ( 95.5 percent), while for white-collar workers and blue-collar workers the difference is approximately 40 percent and 13 percent, respectively.

\footnotetext{
${ }^{16}$ Many government pension plans require employee contributions, but this is not a common requirement in the private sector. Almost all private workers and many government employees are covered by Social Security. Federal employees generally have full automatic cost-of-living adjustments, while just six percent of private plans are adjusted.

${ }^{17}$ Benefits in the private sector make up 33.2 percent of compensation costs for blue-collar workers, 27.3 percent for white-collar workers, and 24.5 percent for service occupations. In the public sector, these proportions are 35.7 percent, 28.8 percent, and 36.6 percent, respectively.
} 
Bellante and Long (1981) address the problem of adjusting wage differentials for nonwage compensations and other nonpecuniary job attributes in each sector. They use Smith's (1977) regression results to construct indexes to compare the return to human capital among private, federal, state and local sectors workers, as given by

$$
\exp \sum \hat{\beta}_{\mathrm{gj}} \overline{\mathrm{X}}_{\mathrm{Pj}} / \exp \sum \hat{\beta}_{\mathrm{Pj}} \overline{\mathrm{X}}_{\mathrm{Pj}}
$$

These indexes are then adjusted by the proportion of fringe benefits and the probability of unemployment in each sector (assuming risk neutrality), where $\bar{X}_{\mathrm{p}}$ represents the average characteristics of workers in the private sector, and $\hat{\beta}_{\mathrm{sj}}$ is the $j$ th coefficient estimated in the wage equation for sector $s$ (with $\mathrm{s}=$ federal, state, local, and private). These indexes are interpreted as a measure of sectoral differences in the payoffs in human capital, and other qualities weighted by average private labor force characteristics. Their findings, after adjusting for other benefits and job security, confirm that the total compensation for public workers at all levels of government is higher than that of comparable workers in the private sector.

Even though it is difficult to compare total compensation in each sector, the advantages enjoyed by government workers can be summarized as follows (Cox and Brunelli, 1994): more generous fringe benefits; more paid vacations days, holidays, and personal days off; more sick time off; value of excess paid benefits free from federal and state income taxes, larger annual compensations increases and lower productivity, with shorter work weeks; greater job security; generous severance pay; earlier retirement, including routine pension benefit increases and paid retiree health care. The general evidence tends to indicate that differences in nonwage benefits reinforce wage differentials apparently enjoyed by public sector workers. Total compensation inequality seems to be larger than wage inequality, with a the public sector premium increasing as one moves from the top to the bottom of the earnings distribution. In any case, the magnitude of the gap is sensitive to the inclusion of specific explanatory variables in the model, particularly narrowly defined job categories and size of establishment.

\section{Conclusion}

Despite the variety of results discussed, a few firm conclusions do seem to be justified. There is a consensus finding that federal government workers are paid a substantial premium when estimates of that premium include non-wage benefits. Below the federal level, the finding of a public sector compensation premium is far less uniform. While the preponderance of evidence seems to be in favor of the existence of a premium for state government employees, the finding receives less support at the local governmental level. However, most studies that find the absence of a premium or even under compensation of public employees at any level tend either to exclude all but monetary wages, or employ variables such as "firm size" that are likely to disguise the existence of a public sector premium, or do both. Note that in all results reported in the appendix table, all concern wages only: Adjustment for non-wage factors (except "firm size") invariably raises the ratio of public to private compensation [e.g., Bellante and Long (1981)]. And even ignoring non-wage factors, all studies surveyed in that table show no undercompensation of public employees at any level when an adjustment is made for selectivity bias. But even among the great majority of studies that do find a government compensation premium, the estimates of the magnitude of the premium vary greatly. It is impossible to reconcile the differences among these magnitudes, as so many factors differ across the studies. It is nonetheless clear that the methods of estimation have not been fully up to the task of controlling for selectivity bias.

A more recent and powerful way to deal with selectivity bias in nonrandomized observational studies is based on matching methods, which have become increasingly popular in medical studies but are not yet widely explored in economics. Matching methods estimate the effect of a treatment by using observed variables to adjust for differences in outcomes unrelated to the treatment that originates the selection bias. In fact, if individuals selfallocate into the treatment, the estimation of the effect of such a treatment may be biased due to the existence of confounding factors. Matching methods control for the observed pre-treatment factors, limiting the comparison of outcomes to paired individuals, which reduces the bias and generates matched control groups that can be used as "virtual" counterfactuals. Among the different matching methods the most common and relatively easier to implement is the one based on propensity scores [Rubin (1973); Rosenbaum and Rubin, (1983)], which also has 
been shown to successfully estimate the treatment impact of a program. In this method, the k-dimension vector of pre-treatment characteristics is summarized into a single variable, called the propensity score that is the probability that the individual is assigned to the treatment.

In economics, the use of matching methods has being limited to the measure of the effect of gender discrimination (Nopo, 2002) or type of education on wages (Becker and Ichino, 2001), and to the impact of jobtraining programs. In this latter regard, the seminal paper by LaLonde (1986) uses the data from the 1970s National Supported Work Demonstration to show how the results of standard nonexperimental estimators such as OLS, fixed effects, and latent variables fail to accurately estimate the impact of training programs. More recent studies have emphasized the role of matching estimators in evaluating the effects of this kind of treatment interventions on wages [Ichimura (1993); Heckman et. al. (1997); Dehejia and Wahba (1999, 2002); Kordas and Lehrer (2002); Abadie and Imbens (2002)], most of them based on propensity score methods. However, the potential use of propensity score matching estimators to compare the public and private sector wages has been ignored so far. Perhaps the use of matching methods will lead to a definitive conclusion, not only about the existence but also about the magnitude of public sector compensation premia. If previous notions of substantial premia are supported such that confidence may be placed in the estimates of magnitude, the major questions will no longer be empirical, but will concern the implications for public policy - both theoretical and practical.

\section{References}

1. Abadie, Alberto and Imbens, Guido. "Simple and Bias-Corrected Matching Estimators for Average Treatment Effects." Mimeo,University of California at Berkeley (2002).

2. Acemoglu, Daron. "Technical Change, Inequality, and the Labor Market." Journal of Economic Literature 40 (March, 2002): 7-72.

3. Becker, Sascha O. and Ichino, Andrea. "Estimation of Average treatment Effects Based on the Propensity Scores." The Stata Journal 2, no. 4 (2002): 358-377.

4. Bellante, Don and Link, Albert N. "Are Public Sector Workers More Risk Averse than Private Sector Workers?” Industrial and Labor Relations Review 34, no. 3 (April 1981): 408-412.

5. _ and Long, James E. "The Political Economy of the Rent-Seeking Society: The Case of Public Employees and Their Unions.” Journal of Labor Research 2, no. 1 (Spring 1981): 1-14.

6. Belman, Dale; Franklin, Thomas; and Heywood, John S. "Comparing Public and Private Earnings Using State Wage Surveys.” Journal of Economic and Social Measurement 20, no. 2 (May 1994): 79-94.

7. Belman, Dale and Heywood, John S. "Government Wage Differentials: A Sample Selection Approach." Applied Economics 21 (1989): 427-438.

8. . "The Truth about Public Employees: Underpaid or Overpaid?" Economic Policy Institute (April 1993a): $1-23$.

9. _ _Job Attributes and Federal Wage Differentials." Industrial Relations 32, no. 1 (1993b): 148-157.

10. “ "State and Local Government Wage Differentials: an Intrastate Analysis." Journal of Labor $\overline{\text { Research }} 16$ (Spring 1995): 187-201.

11. Bernhardt, Annette; Morris, Martina; Handcock, Mark; and Scott, Marc. "Trends in Job Stability and Wages for Young Adult Men.” Journal of Labor Economics 17, no. 4, part 2 (October 1999): s65-s90.

12. Blank, Rebecca M. "An Analysis of Worker's Choice Between Employment in the Public and Private Sectors." Industrial and Labor Relations Review 38 (1985): 211-224.

13. Bollinger, Christopher R. "Measurement Errors in the CPS: A Nonparametric Look." Journal of Labor Economics 16, no. 3 (July 1998): 576-594.

14. Borjas, George J. "The Wage Structure and the Sorting of Workers into the Public Sector." Working Paper, no. 9313. NBER, October 2002.

15. Bound, John and Johnson, George. "Changes in the Structure of Wages in the 1980's: An Evaluation of Alternative Explanations." American Economic Review 82, no. 3 (June 1992): 371-392.

16. Braden, Bradley R. and Hyland, Stephanie L. "Cost of Employee Compensation in Public and Private Sectors." Monthly Labor Supply (May 1993): 14-21.

17. Brown, Charles. "Equalizing Differences in the Labor Market." Quarterly Journal of Economics 94, no. 1 (February 1980): 113-134. 
18. Buckely, John E. "Pay in Private Industry and State and Local Governments, 1994." Compensating and Working Conditions (September 1996): 22-26.

19. Choudhury, Sharmila. "New Evidence on Public Sector Wage Differentials." Applied Economics (March 1994): 259-271.

20. Cox, Wendell. "U.S. Federal Employee Pay is Above Market." The Public Purpose 3 (March 1996): 1-7.

21. and Brunelli, Samuel A. "America's Protected Class: The Excess Cost of Government Employment in U.S." American Legislative Exchange Council, Washington, D.C., 1994.

22. Dehejia, Rajeev H. and Wahba, Sadek. "Causal Effects in Non-Experimental Studies: Re-evaluating the Evaluation of Training Programs." Journal of the American Statistical Association 94, no. 448 (1999): 1053-1062.

23. . "Propensity Score-Matching Methods for Non-experimental Causal Studies." Review of Economics and Statistics 84 (2002): 151-161.

24. Diebold, Francis X.; Neumark, David; and Polsky, Daniel. "Job Stability in United States." Journal of Labor Economics 15, no. 2 (April 1997): 206-233.

25. Duncan, Gregory M. and Leigh, Duane E. "The Endogeneity of Union Status: An Empirical Test." Journal of Labor Economics 3, no. 3 (1985): 385-402.

26. Ehrenberg, Ronald G. and Schwarz, Joshua L. "Public-Sector Labor Markets." In Handbook of Labor Economics, vol. 2, edited by O. Ashenfelter and R. Layard, chapter 22, Elsevier Science Publishers, 1986.

27. Fishback, Price V. "Operations of 'Unfettered' Labor Markets: Exit and Voice in American Labor Markets at the Turn of the Century." Journal of Economics Literature 36, no. 2 (June 1998): 722-765.

28. Foster, Ann C. "Public and Private Sector Defined Benefit Pensions: A Comparison." Compensation and Working Conditions (Summer 1997): 37-43.

$29 . \quad$. "Private Sector Employee Benefits, 1996-97." Compensating and Working Conditions (Summer 2000): 17-22.

30. Gottschalk, Peter and Moffit, Robert. "Changes in Job Instability and Insecurity Using Monthly Survey Data." Journal of Labor Economics 17, no. 4, part 2 (October 1999): s91-s126.

31. Gregory, Robert G. and Borland, Jeff. "Recent Developments in Public Sector Labor Markets." In Handbook of Labor Economics, vol. 3, edited by O. Ashenfelter and D. Card, chapter 53, Elsevier Science Publishers, 1999.

32. Gronau, Reuben. "Wage Comparison. A Selectivity Bias.” Journal of Political Economy 82, no. 6 (1974): 1119-1143.

33. Gyourko, Joseph and Tracy, Joseph. "An Analysis of Public- and Private- Sector Wages Allowing for Endogenous Choices of both Government and Union Status." Journal of Labor Economics 6, no. 2 (1988): 229-251.

34. Heckman, James. "Shadow Prices, Market Wages, and Labor Supply.” Econometrica 42 (1974): 679-693.

35. _ _ Ichimura, Hidehiko; Smith, Jeffrey; and Tood, Petra. "Matching as an Econometric Evaluation Estimator: Evidence from Evaluating a Job Training Program" Review of Economic Studies 64 (1997): 605654.

36. Herzog, Henry W. and Schlottman Alan M. "Valuing Risk in the Workplace: Market Price, Willingness to Pay, and the Optimal Provision of Safety." Review of Economics and Statistics 72, no. 3 (August 1990): 463-470.

37. Heywood, John S. "Government Employment and the Provision of Fringe Benefits." Applied Economics 23 (1991): 417-423.

38. Hoffnar, Emily and Greene, Michael. "Gender Discrimination in the Public and Private Sectors: A Sample Selectivity Approach.” Journal of Socio-Economics 21, no. 1(1996): 105-114.

39. Hundley, Greg. "Public- and Private- Sector Occupational Pay Structures." Industrial Relations 30, no. 3 (Fall 1991): 417-434.

40. _ "The Effects of Comparable Worth in the Public Sector on Public/Private Occupational Relative Wages." Journal of Human Resources 28, no. 2 (Spring 1993): 318-342.

50. Ichimura, Hidehiko. " Semiparametric Least Squares (SLS) and Weighted (SLS) Estimation of SingleIndex Models." Journal of Econometrics 58 (1993): 71-120.

51. Ippolito, Richard. "Why Federal Workers Do Not Quit." Journal of Human Resources 22 (1987): 281-99. 
52. Jaeger, David A. and Stevens, Ann H. "Is Job Stability in the United States Falling? Reconciling Trends in the CPS and PSID." Journal of Labor Economics 17, no. 4, part 2 (October 1999): s1-s28.

53. Kaatz, James B. and Morris, John C. "The 'Overpaid Bureaucrat': Comparing Public and Private Wages in Mississippi.” Public Personnel Management 29, no. 1 (Spring 2000): 129-146.

54. Katz, Lawrence F. and Author, A D. "Changes in the Wage Structure and Earnings Inequality." In Handbook of Labor Economics, vol. 3, edited by O. Ashenfelter and D. Card, chapter 26, Elsevier Science Publishers Bv, 1999.

55. and Krueger, Alan B. "Changes in the Structure of Wages in the Public and Private Sectors."

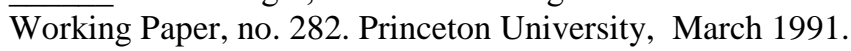

56. Kordas, Gregory and Lehrer, Steven F. "Matching using Semiparametric Propensity Scores." Mimeo, University of Pennsylvania (2002).

57. Kroncke, Charles O. and Long, James E. "Pay Comparability in State Government." Journal of Labor Research 19, no. 2 (Spring 1998): 371-385.

58. Krueger, Alan B. "Are Public Sector Workers Paid More than their Alternative Wage? Evidence from Longitudinal Data and Job Queues.” Working Paper, no. 225. Industrial Relations Section, Princeton University, 1987.

59. _ and Summers, Lawrence H. "Efficiency Wages and the Inter-Industry Wage Structure." Econometrica 56, no. 2 (March 1988): 259-293.

60. LaLonde, Robert. "Evaluating the Econometric Evaluations of Training Programs." American Economic Review 76, no. 4 (1986): 604-620.

61. Leete, Laura. "Whither the Nonprofit Wage Differential? Estimates from the 1990 Census." Journal of Labor Economics 19, no. 1 (January 2001): 136-170.

62. Linneman, Peter D. and Wachter, Michael L. "The Economics of Federal Compensation." Industrial Relations 29, no. 1 (Winter 1990): 58-76.

63. Long, James E. “Are Government Workers Overpaid? Alternative Evidence.” Journal of Human Resources 14 (1982): 41-62.

64. Lovejoy, Lora M. "The Comparative Value of Pensions in the Public and Private Sectors." Monthly Labor Review (December 1988): 18-26.

65. Lucas, Robert. "Hedonic Wage Equations and Psychic Wages in the Returns to Schooling." American Economic Review 67, no. 4 (September 1977): 549-558.

66. Miller, Michael A. "The Public-private Pay Debate: What Do the Data Show?" Monthly Labor Review (May 1996): 18-29.

67. Mincer, Jacob. "The Distribution of Labor Incomes: A Survey with Special Reference to the Human Capital Approach.” Journal of Economic Literature 8 (March 1970): 1-26.

68. Mitchell, Olivia S. and Smith, Robert. "Pension Funding in the Public Sector." Review of Economics and Statistics 76, no. 2 (May 1994): 278-290.

69. Moffitt, Robert A. "New Developments in Econometric Methods for Labor Market Analysis." In Handbook of Labor Economics, vol. 3, edited by O. Ashenfelter and D. Card, chapter 24, Elsevier Science Publishers, 1999.

70. Moore, William J. and Raisian, John. "Government Wage Differentials Revisited." Journal of Labor Economics 12, no. 1 (Winter 1991): 13-34.

71. Moulton, Brent R. "A Reexamination of the Federal-Private Wage Differential in the United States." Journal of Labor Economics 8, no. 2 (April 1990): 270-293.

72. Musell, Mark and Masia, Neal. "Reconciling Differences in Federal and Private Sector Pay Comparisons." Public Budgeting and Finance (Spring 1998): 68-77.

73. Nopo, Hugo. "Matching as a Tool to Decompose Wage Gaps." Job Market Paper. Northwestern University (2002).

74. Poterba, James M. and Rueben, Kim S. "The Distribution of Public Sector Wage Premia: New Evidence Using Quantile Regression Methods.” Working Paper, no. 4734. NBER, May 1994.

75. Quinn, Joseph F. "Pension Wealth of Government and Private Sector Workers." American Economic Review 72, no. 2 (May 1982): 283-287.

76. Rosenbaum, Paul and Rubin, D. "The Central Role of the Propensity Score in Observational Studies for Causal Effect." Biometrika 70, no. 1 (1983): 41-55. 
77. Rubin, D. "Matching to Remove Bias in Observational Studies." Biometrics 29 (1973): 159-183.

78. Schwenk, Albert E. "Compensation Cost Trends in Private Industry and State and Local Governments." Compensation and Working Conditions (Fall 1999): 13-18.

79. Smith, Sharon P. "Pay Differentials Between Federal Government and Private Sector Workers." Working Paper, no. 53. Industrial Relations Section, Princeton University, September 1974a.

$80 . \quad$. "Government Wage Differentials by Region and Sex." Working Paper, no. 58. Industrial Relations Section, Princeton University, December 1974b.

81. _ _ “Government Wage Differentials." Journal of Urban Economics 4, (1977): 248-271.

82. “ "Public/private Wage Differentials in Metropolitan Areas." In Public Sector Labor Markets, edited by P. Mieszkowski and G. E. Peterson, Washington D.C.,1981.

83. _ "Prospects for Reforming Federal Pay." American Economic Review 72, no. 2 (May 1982): 273277.

84. Van Ophem, Hans. "A Modified Switching Regression Model for Earnings Differentials Between the Public and Private Sectors in the Netherlands." Review of Economics and Statistics 75, no. 2 (May 1993): 215-224.

\section{Appendix}

\begin{tabular}{|c|c|c|c|c|c|c|c|c|c|}
\hline \multicolumn{10}{|c|}{$\begin{array}{cc}\text { Table } 1 \\
\text { Estimated Public/Private-Sector Wage }\end{array}$} \\
\hline \multirow[t]{2}{*}{ Study / year of the data } & \multicolumn{3}{|c|}{ Federal } & \multicolumn{3}{|c|}{ State } & \multicolumn{3}{|c|}{ Local } \\
\hline & Male & Female & All & Male & Female & All & Male & Female & All \\
\hline Smith (1973) & 20.0 & 38.0 & & -3.0 & 14.0 & & -7.0 & 6.0 & \\
\hline Smith (1975) & 15.0 & 21.0 & & -7.0 & 6.0 & & -7.0 & 1.0 & \\
\hline Bellante-Long (1975) & 18.0 & 24.0 & 20.0 & -3.0 & 8.0 & 2.0 & -4.0 & -2.0 & -5.0 \\
\hline Smith (1978) & 11.0 & 21.0 & & 2.0 & 11.0 & & -4.0 & -2.0 & \\
\hline Moulton (1977) & \multicolumn{3}{|c|}{$[-4.5,4.0]$} & & & & & & \\
\hline Wachter-Perloff (1978) & \multicolumn{3}{|l|}{34.0} & \multicolumn{3}{|l|}{16.0} & \multicolumn{3}{|l|}{7.0} \\
\hline Moore-Raisian (1980s) & \multicolumn{3}{|c|}{9.7} & \multicolumn{3}{|l|}{-3.3} & \multicolumn{3}{|l|}{-2.7} \\
\hline Belman-Heywood (1983) & \multicolumn{3}{|c|}{5.8} & & & & & & \\
\hline $\begin{array}{l}\text { Linneman-Wachter } \\
\text { (1983) }\end{array}$ & \multicolumn{3}{|l|}{16.9} & & & & & & \\
\hline \multicolumn{10}{|l|}{ Conditioned to selection } \\
\hline Gyourko-Tracy (1977) & \multicolumn{3}{|c|}{18.9 (18.2 w/o selection) } & \multicolumn{3}{|c|}{1.3 (0.9 w/o selection) } & \multicolumn{3}{|c|}{$2.0 \quad(0.9$ w/o selection } \\
\hline Hundley (1985) & \multicolumn{3}{|c|}{0.0} & \multicolumn{3}{|c|}{23.0} & \multicolumn{3}{|c|}{20.0} \\
\hline Hoffnar-Greene (1996) & \multirow{2}{*}{\multicolumn{3}{|c|}{$\begin{array}{ll}22.0 & \text { (34 w/o selection }) \\
260 & 190\end{array}$}} & & & & & & \\
\hline Choudhury (1991) & & & & & & & & & \\
\hline
\end{tabular}


Notes 